\title{
Expanding the repertoire of electron acceptors for the anaerobic oxidation of methane in carbonates in the Atlantic and Pacific Ocean
}

\author{
Sabrina Beckmann $\mathbb{D}^{1,3}$ - Ibrahim F. Farag ${ }^{1} \cdot$ Rui Zhao ${ }^{1}$ Glenn D. Christman ${ }^{1}$ Nancy G. Prouty ${ }^{2}$. \\ Jennifer F. Biddle $\mathbb{B}^{1}$
}

Received: 12 June 2020 / Revised: 21 January 2021 / Accepted: 29 January 2021 / Published online: 12 March 2021

(c) The Author(s), under exclusive licence to International Society for Microbial Ecology 2021

\begin{abstract}
Authigenic carbonates represent a significant microbial sink for methane, yet little is known about the microbiome responsible for the methane removal. We identify carbonate microbiomes distributed over 21 locations hosted by seven different cold seeps in the Pacific and Atlantic Oceans by carrying out a gene-based survey using 16S rRNA- and mcrA gene sequencing coupled with metagenomic analyses. Based on 16S rRNA gene amplicon analyses, these sites were dominated by bacteria affiliated to the Firmicutes, Alpha- and Gammaproteobacteria. ANME-1 and -2 archaeal clades were abundant in the carbonates yet their typical syntrophic partners, sulfate-reducing bacteria, were not significantly present. Based on $m c r A$ amplicon analyses, the Candidatus Methanoperedens clades were also highly abundant. Our metagenome analysis indicated that methane oxidizers affiliated to the ANME-1 and -2, may be capable of performing complete methane- and potentially short-chain alkane oxidation independently using oxidized sulfur and nitrogen compounds as terminal electron acceptors. Gammaproteobacteria are hypothetically capable of utilizing oxidized nitrogen compounds and may be involved in syntrophy with methane-oxidizing archaea. Carbonate structures represent a window for a more diverse utilization of electron acceptors for anaerobic methane oxidation along the Atlantic and Pacific Margin.
\end{abstract}

\section{Introduction}

Authigenic carbonates consisting of different minerals and growing in various sizes and morphologies form at cold seeps precipitating at or near the sediment-water interface or buried within the sediment column, with chemosynthetic communities such as mussels and microbial mats attached

These authors contributed equally: Sabrina Beckmann, Ibrahim F. Farag

Supplementary information The online version contains supplementary material available at https://doi.org/10.1038/s41396021-00918-w.

Jennifer F. Biddle

jfbiddle@udel.edu

1 School of Marine Science and Policy, University of Delaware, Lewes, DE, USA

2 USGS Pacific and Coastal Marine Science Center, Santa Cruz, CA, USA

3 Present address: Department of Microbiology and Molecular Genetics, Oklahoma State University, Stillwater, OK, USA to exposed carbonates [1-10]. Cold seeps vary in their degree of activity ranging from intense gas discharge to dormant sites, and changes in activity can occur over time $[11,12]$. Several hundred seeps can be found along the United States Atlantic over a large range of depths within and outside the gas hydrate stability zone [13], similar to along the Pacific Margin [14], with active seafloor fluid seepage recently documented along the Queen Charlotte Fault [15]. The removal of methane from seeps plays a significant role in the marine carbon cycle and occurs predominantly via microbial anaerobic oxidation of methane (AOM) $[16,17]$ representing a long-term storage and sink via the formation of methane-derived authigenic carbonates [18-20].

AOM can be mediated by symbiotic consortia of anaerobic methane-oxidizing archaea (methanotrophs, ANME) and sulfate-reducing (SRB) or sulfur-disproportionating bacteria [21-29]. Three distinct ANME clades and their subgroups distantly related to the Methanosarcinales and Methanomicrobiales, have been identified in association with sulfate reducing bacteria: ANME-1 (ANME-1a,1b), ANME-2 (ANME-2a-c) and ANME3. Members of ANME1 and ANME-2 in association with SRB affiliated to the 
Desulfosarcina/Desulfococcus group [30] and ANME-3 found in association with the members of the Desulfobulbus group $[31,32]$ have been detected oxidizing the seafloor methane and channeling reducing equivalents to their syntrophic partner [3, 8]. Electrons generated from methane oxidation are likely transferred into nitrate or sulfate through cytochromes mediating electron transfer from ANME to syntrophic sulfate reducing bacteria as described in previous studies [33-35]. AOM coupled to sulfate increases the alkalinity of the porewater promoting the precipitation of calcium carbonate by producing two units of alkalinity per one unit of dissolved inorganic carbon resulting in the formation of alkaline ${ }^{13} \mathrm{C}$-depleted carbonates [9, 36-40]. Isotopic analysis, lipid biomarker and $16 \mathrm{~S}$ rRNA gene analyses revealed the presence and activity of ANMEs carrying out the AOM and favoring the precipitation of methane-derived authigenic carbonates $[1,5,36,40$ 48]. AOM coupled to sulfate reduction has been most extensively studied due to the abundance of sulfate in marine systems. Nitrate, nitrite and metal oxides can also act as electron acceptors of AOM mediated by members of the archaeal family Candidatus Methanoperedenaceae, formerly known as ANME-2d [49-52]. These electron acceptors have been mostly overlooked in deep marine environments.

Previous investigations from well-studied seep sites showed that carbonates in the Black Sea and at Hydrate Ridge in the Pacific Ocean host active bacterial communities consisting predominantly of Alpha-, Gamma-, and Deltaproteobacteria and archaeal communities notably dominated by ANME-1a-b but also members of ANME-2a$\mathrm{c}$ and the thaumarchaeotal lineage Marine Benthic Group B [29, 43, 46, 47, 53, 54]. Bacterial communities were more dependent on the physical substrate type of the carbonate sites, whereas archaeal members affiliated to ANME groups were more dependent on the methane flux activity [45]. Microbial communities of carbonate are dynamic and react to seepage activity [53]. However, much is still unknown about the microbiome of deep-sea carbonates, including the large-scale biogeography.

In this study, we describe the mineralogy, chemical parameters, and the microbial community structures and functions of the carbonates at acive seep sites sampled from the Atlantic and Pacific margins. We employed single gene diversity surveys using both $16 \mathrm{~S}$ rRNA and $m c r A$ genes in association with metagenomics to investigate 21 carbonate samples isolated from seven different seep sites across the Atlantic and Pacific Oceans. Our analyses focused on comparing the microbial community structures of these geographically distinct authigenic carbonates, investigating their methaneoxidizing communities and identifying the repertoire of the electron acceptors that could be potentially utilized by these microbes and/or their proposed syntrophic partners.

\section{Materials and methods}

\section{Sample collection and study site}

Authigenic carbonate samples were collected from cold seeps along the United States Atlantic Margin (USAM) and Pacific Margin as part of regional efforts to better understand the linkages between geology, tectonics, biology, and methane availability along a passive margin and transform fault. In 2012, 2013, 2017, and 2018 authigenic carbonates were collected from Norfolk Canyon, Baltimore Canyon, Washington Canyon, Chincoteague, Pea Island and Blake Ridge near previously identified USAM methane seeps from a large range of depths including well within the gas hydrate stability zone, and less than $500 \mathrm{~m}$ water depth, outside the methane hydrate stability field $[9,13,55,56]$. Samples were collected onboard the NOAA ship Nancy Foster (NF-12-14) using the Kraken II ROV (University of Connecticut, USA), the NOAA ship Ronald H. Brown (RB13-05) using the Jason II ROV (Woods Hole Oceanographic Institution, USA), the R/V Hugh Sharp (HRS-1704) using the Global Explorer (Oceaneering, 2017), and $\mathrm{R} / \mathrm{V}$ Atlantis (AT41) using the Deep Submergence Vehicle Alvin (Woods Hole Oceanographic Institution, USA). Along the Queen Charlotte Fault, authigenic carbonate samples were collected onboard the R/V John P. Tully in 2011, 2015, and 2017 by either a grab sampler developed capable of collecting 1-m [3] sample of relatively undisturbed sediment or rock, or from a piston corer at water depths ranging from 507 to $1003 \mathrm{~m}$ [15]. When available, bottom water and pore water sampling associated with the authigenic carbonates was accomplished using Niskin bottles and push cores, respectively (Supplementary Table 1 and Supplementary Fig. 1). Samples were immediately processed in the laboratory as outlined below.

\section{Carbonate and water chemical analyses}

Upon collection, carbonate samples were frozen for storage until analysis. A portion of each carbonate sample was homogenized to a fine powder in preparation for inorganic geochemical analysis. Subsamples were used to determine carbon content, stable isotope composition, and mineralogy following methods described in Prouty et al. [9, 10]. In brief, carbon content was measured by a UIC Coulometrics CM5012 $\mathrm{CO}_{2}$ coulometer via combustion (USGS Sediment Laboratories, Santa Cruz, CA), carbonate carbon $\left(\delta^{13} \mathrm{C}\right)$ and oxygen $\left(\delta^{18} \mathrm{O}\right)$ isotope composition was determined using Thermo-Finnigan MAT 253 with a Kiel IV Automated Carbonate Prep Device (University of California, Santa Cruz Stable Isotope Lab), and mineralogy was determined by X-ray diffraction (XRD) using a Philips XRD with 
graphite monochromator at $40 \mathrm{kV}$ and $45 \mathrm{~mA}$ (USGS Marine Minerals Laboratory, Santa Cruz, CA).

Porewater samples were extracted using Rhizon samplers $(0.15 \mu \mathrm{m}$ pore size $)$ [57] inserted into the liner of either sediment push cores or piston cores and stored frozen. Sediment surface water was collected from the push cores using a vacuum pump and bottom water samples were collected using a Niskin directly attached to the ROV or CTD rosette and filtered using an in-line $0.45 \mu \mathrm{m}$ filter. Nutrients were analyzed via flow injection analysis for $\mathrm{NH}_{4}{ }^{+}, \mathrm{Si}, \mathrm{PO}_{4}{ }^{3-}$, and $\left[\mathrm{NO}_{3}{ }^{-}+\mathrm{NO}_{2}{ }^{-}\right]$, with precisions of $0.6-3.0 \%, 0.6-8 \%$, $0.9-1.3 \%$, and $0.3-1.0 \%$ relative standard deviations, respectively at the University of California at Santa Barbara's Marine Science Institute Analytical Laboratory.

\section{DNA extraction}

Authigenic carbonates were crushed and homogenized aseptically using a homogenizer. The carbonate homogenate was subsequently transferred to sterile power bead tubes provided by Qiagen (Hilden, Germany). DNA was then extracted using the DNeasy ${ }^{\oplus}$ Ultra Clean ${ }^{\oplus}$ Microbial Kit according to the manufacturer's instructions (Qiagen). The DNA pellet was washed with $70 \%(\mathrm{v} / \mathrm{v})$ ethanol and resuspended in $50 \mu \mathrm{L}$ nuclease free water (Qiagen). Agarose gel electrophoresis and a RiboGreen assay (Qubit Assay Kit, Invitrogen, Life Technologies Corporation, Oregon, USA) were used to analyze the DNA concentration and purity according to the manufacturer's instructions. The extracted DNA was used as template for bacterial and archaeal 16S rRNA gene and mcrA gene, encoding for the methyl coenzyme $M$ reductase, sequencing as well as for metagenomic sequencing.

\section{$16 S$ rRNA and $m c r A$ gene sequencing}

Amplicon libraries were generated from the DNA by following Illumina's 16S Sequencing Library Preparation Protocol. The universal primer pair 515F/806R targeting the V4 hypervariable region of the bacterial and archaeal $16 \mathrm{~S}$ rRNA genes [58-60] and the mcrA primer pair $m c r A F / m c r A R$ encoding for the methyl coenzyme $M$ reductase [61] were used for the initial amplification. PCR products were purified using the GeneJET Gel Extraction Kit (ThermoFisherScientific, Vilnius, Lithuania) and quantified using a fluorometric RiboGreen kit (Qubit Assay Kit, Invitrogen, Life Technologies Corporation, Oregon, USA) according to the manufacturer's instructions. Purified amplicons were multiplex sequenced using the Illumina MiSeq platform (Microbial Analysis, Resources and Services, UConn Biotechnology Bioservices Center, Stamford, CT, USA) according to Lange et al. [62] Denoising chimera removal and trimming of poor quality read ends were performed using QIIME 1.9.1. (https:// qiime.org) [58] Reads were clustered into OTUs with $>97 \%$ sequence similarity using the uclust_ref algorithm [63] and the SILVA Database (v.132; https://www.arb-silva.de) [64]. Statistical analyses of the datasets were carried out according to Clarke [65] using R (Vienna, Austria) and XLSTAT (AddinSoft, Paris, France).

\section{Metagenomic community profiling}

Metagenomic libraries were prepared from the carbonate samples collected from Norfolk Canyon and Queen Charlotte Fault sites. DNA sequencing was conducted at the University of Delaware DNA Sequencing and Genotyping Center (Newark, DE, USA) on an Illumina NextSeq sequencer. The raw sequencing data were processed with Trimmomatic [66] to remove Illumina adapters and low quality reads ("SLIDINGWINDOW:10:25"). The qualitycontrolled reads from the two samples were de novo coassembled into contigs using Megahit v.1.1 [67] with the kmer length varying from 27 to 117 . Contigs longer than $1000 \mathrm{bp}$ were automatically binned using MaxBin2 [68]. The resulting MAGs were quality assessed using CheckM [69]. Genome bins of $>50 \%$ completeness were manually refined using Vizbin based on t-SNE signatures [70] and the gbtools [71] based on the GC content, taxonomic assignments, and differential coverages in different samples. Coverages of contigs in each sample were determined by mapping trimmed reads onto the contigs using BBMap v.37.61 [72]. Taxonomy of contigs were assigned according to the taxonomy of the single copy marker genes in contigs identified using a script modified from blobology [73] and classified by BLASTn. To improve the quality of the recovered genomes, we recruited reads from highestabundance-sample (i.e., highest genome coverage) using BBMap as described above, and the recruited reads were reassembled using SPAdes v.3.12.0 [74]. After removal of contigs shorter than $1 \mathrm{~kb}$, the resulting scaffolds were visualized and re-binned manually using gbtools [71] as described above. The quality of the resulting MAGs were checked using CheckM v.1.0.7 [69] with the "lineage_wf" option. MAGs were dereplicated using dRep (version v2.0.5 with ANI > 99\%) [75] and the most complete MAG per group was selected for downstream analyses. Encoded proteins were predicted using Prodigal v2.6.3 applying the default translation table [76]. Contigs were annotated using Prokka v.1.1268 [77]. Proteins were queried against the KEGG database using GhostKOALA [78].

\section{Phylogenomic and phylogenetic analysis}

Phylogenomic positions of the recovered MAGs were primarily evaluated using a concatenated alignment of 120 single copy marker genes implemented in GTDB_TK for the bacterial MAGs and 122 single copy marker genes for the 
archaeal MAGs. The phylogenomic positions of the MAGs were further confirmed via a single phylomarker gene approach. We primarily used the small ribosomal protein 3 (RPS3), which is commonly used in phylogenetic analysis because of its known strong phylogenetic signals [79, 80]. In cases where the MAGs were missing RPS3, the taxonomic positions of the MAGs were confirmed using RPL2. Maximum-likelihood trees were calculated based on two single ribosomal proteins (L2 and S3) using IQ-Tree (v1.6.6) [81] (located on the CIPRES web server) [82]. Evolutionary distances were calculated based on best fit substitution model (VT $+\mathrm{F}+\mathrm{R} 10)$, and single branch location was tested using 1000 ultrafast bootstraps and approximate Bayesian computation, branches with bootstrap support $>80 \%$ were marked by black circles. Also, the Putative taxonomic ranks for obtained MAGs were further evaluated using average Amino Acid Identity and the taxonomic affiliations of the contigs using blastn against non-redundant (nr) and UniProtKB databases.

\section{Metabolic reconstruction and functional annotation of the MAGs}

Predicted proteins from all MAGs were screened using HMM search tool against modified custom HMM databases [83] representing the key genes for different microbial energy metabolism (electron donors and acceptors), and various biogeochemical cycles including sulfur and nitrogen (see supplementary material for HMM databases). The completion of the pathways was assessed through querying the predicted proteins against KEGG database using BlastKoala tool [78].

\section{Functional protein-based trees}

All functional protein-based trees were built by aligning the query protein sequences to the reference sequences belonging to the same protein family using Muscle v3.8.31 [84]. Reference sequences were collected from AnnoTree using the corresponding KEGG entry as search keyword [85]. Aligned sequences were manually curated using Geneious v9.0.5 (https://www.geneious.com). The phylogenetic trees were computed using IQ-TREE (v1.6.6) [81], through the CIPRES web server and the evolutionary relationships were described using the best fit model. Branch locations were tested using 1000 ultrafast bootstraps and approximate Bayesian computation. The McrA alignment is available in the supplementary material.

\section{Results and discussion}

This study examined 21 carbonate samples representing 7 different authigenic carbonate-based methane seeps from the Atlantic and Pacific Margin. Geochemical and mineralogical examinations were performed on carbonate material and the surrounding environment. Microbial community compositions were assessed based on $16 \mathrm{~S}$ rRNA gene analysis. The key microbial players of the methane cycle in the authigenic carbonates were identified using a large scale mcrA gene-based survey. The overall functions of the microbial communities and potential metabolic interactions were evaluated through metagenomic and metagenome-assembled genomes (MAG) analyses.

\section{Geochemical characteristics of authigenic carbonates in spatially distributed seep environments}

Composition and geochemical characteristics of authigenic carbonates collected from seven different active seep sites, located in the along the Atlantic and Pacific Margins, were analyzed (Fig. 1, Table 1, Table S1). Carbonates were sampled from different water depths ranging from 342 to $2169 \mathrm{~m}$ between the years 2012 and 2018 and are aragonite dominated, with contributions from dolomite, calcite, and quartz (Table 1). The $\delta^{13} \mathrm{C}$ and $\delta^{18} \mathrm{O}$ values indicate a variety of processes and fluids involved in the formation of each carbonate, considering the wide range in values (Table 1). For example, the range in carbonate $\delta^{13} \mathrm{C}$ values suggests mixing between microbial methane and thermogenic hydrocarbon sources [86], whereas the $\delta^{18} \mathrm{O}$ values indicate potential influence from ${ }^{18} \mathrm{O}$-enriched fluid source. At select seep sites, bottom water and porewater from push cores were taken next to the carbonate sampling sites and measured for nutrient concentrations (Table S1). The sediment surface and bottom water revealed nitrite and nitrate concentration up to $3.95 \mu \mathrm{M}$ and up to $23.59 \mu \mathrm{M}$, respectively. The porewater was characterized by high ammonium concentrations ranging from 17 to $163 \mu \mathrm{M}$. Carbonates represent a habitat structure were methane comes in contact with nitrate and nitrite, suitable oxidants for AOM. Sulfate is abundant in seawater and sulfate-dependent AOM was detected in seawater systems with sulfate concentrations of $2 \mathrm{mM}$ sulfate or lower [42, 87-89]. As such, multiple electron acceptors may be available for methane oxidation. As a caveat, since methane oxidation was not tested via geochemistry, we are using the microbial community to serve as indicators of potential methane oxidation. However, it has been shown that carbonate structures have malleable microbial communities and microbial composition may reflect age or seepage activity [53]. All of our samples were collected within $20 \mathrm{~m}$ of active seepage activity (Fig. 1). 

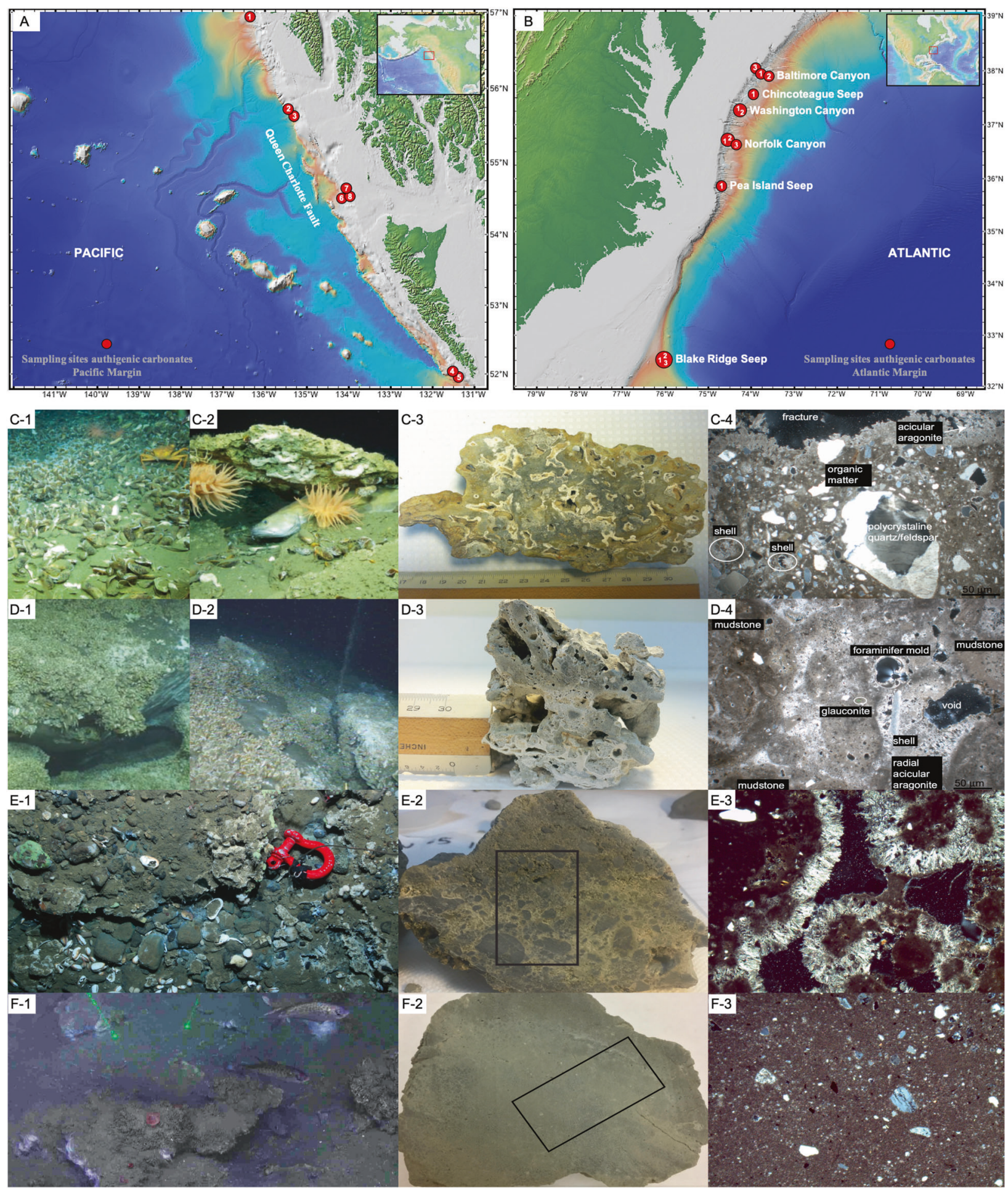

Fig. 1 Map of sample locations, photos of samples. Map of the Pacific (A) and Atlantic Margin (B), red circles indicate the locations of origin of the authigenic carbonate samples used in this study, accompanied by images showing the carbonate collection at Baltimore Canyon (C1-2), Norfolk Canyon (D1-2) and Queen Charlotte Fault (E1, F1) and the sampled carbonates and their structure (C3-4, D3-4, E2-3, F2-3). Samples were collected at Baltimore Canyon, Norfolk

Canyon, Washington Canyon, Chincoteague Seep, Pea Island Seep and Blake Ridge Seep on the Atlantic Margin and along Queen Charlotte Fault on the Pacific Margin at water depths ranging from 342 to $2169 \mathrm{~m}$ and 492 to $1003 \mathrm{~m}$, respectively. The base map is derived from Global Multi-Resolution Topography (GMRT) [99], GeoMapApp. 


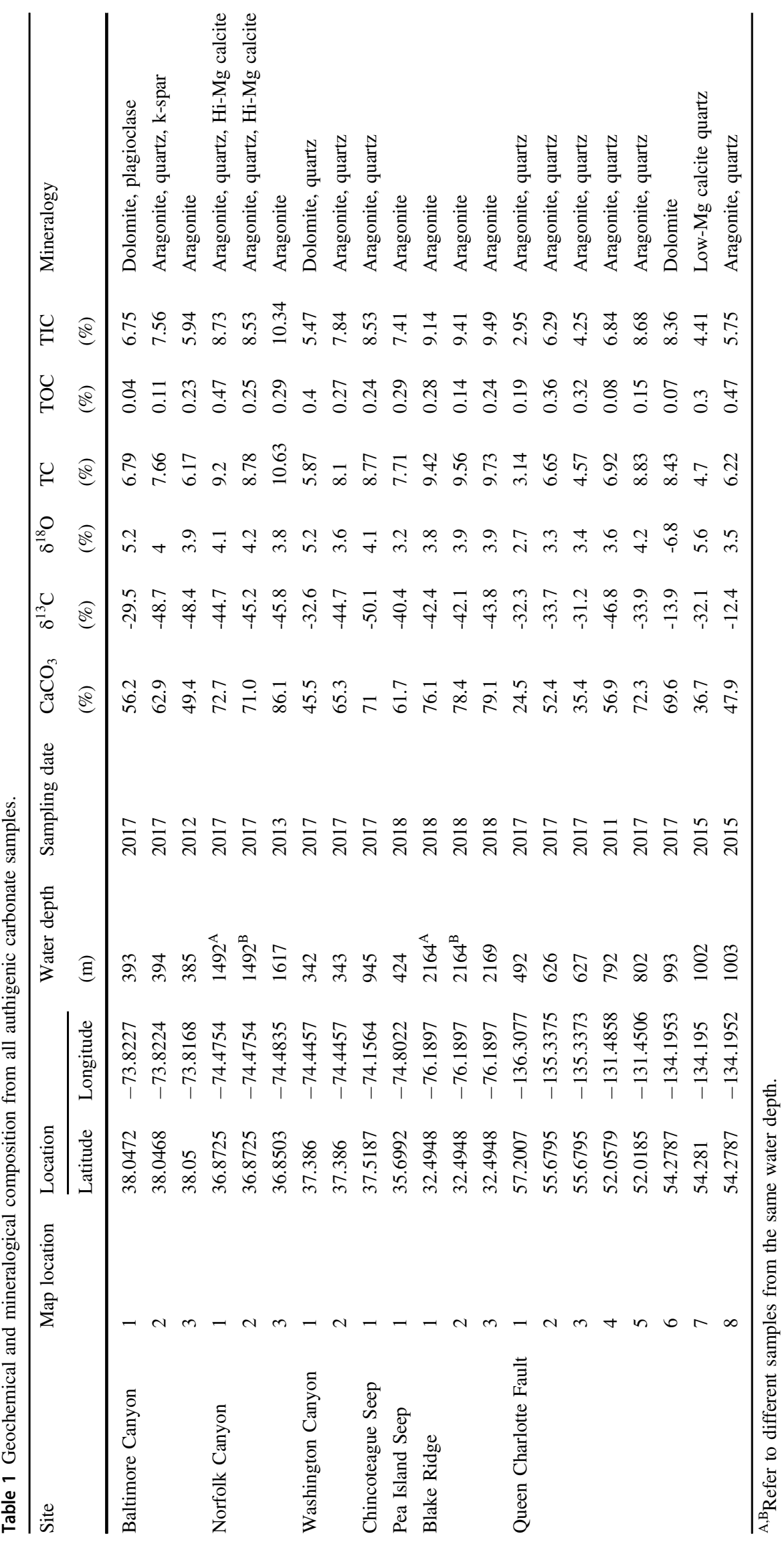




\section{Microbial community structures of the Atlantic and Pacific Margin carbonates show a disconnection between ANME and SRB}

The microbial community compositions in all carbonates from the Atlantic and Pacific Margins were analyzed using gene-based approach targeting both 16S rRNA and mcrA gene sequences (Fig. 1). Both bacterial and archaeal lineages were represented in all carbonate samples from all sampling sites of the Atlantic and Pacific Margin via 16S rRNA gene sequencing (Fig. 2). The 16S rRNA gene analyses indicated that bacterial communities comprise $70-90 \%$ of the total microbial communities and were dominated by lineages belonging to Alpha- and Gammaproteobacteria, Firmicutes, and Bacteroidetes (Fig. 2). Euryarchaeota dominated the archaeal communities, comprising up to $31 \%$ of the total microbial community composition harboring predominantly archaea affiliated to the ANME-1, ANME-2 and ANME-3 clades. No methanogenic archaea were detected via the $16 \mathrm{~S}$ rRNA gene amplicon analysis.

We found multiple bacterial lineages belonging to different metabolic groups that could serve as potential syntrophic partners for the ANME. This is consistent with previous results from Norfolk and Baltimore Canyon seep sites where AOM was found to be tightly coupled to both sulfate and nitrate reduction in a syntrophic relationship [10]. ANME carrying out AOM in syntrophy with SRB is an important process for AOM to occur via reverse methanogenesis facilitated by electron acceptors such as sulfate or nitrate, whilst coupling AOM with nitrate and nitrite reduction yields significantly more energy $[90,91]$.

Across all sites, the highest abundance and diversity of SRB were observed in carbonates sampled from the Norfolk Canyon, Washington Canyon and Blake Ridge, located in the Atlantic Margin (Fig. 2). The sulfate reducing communities were dominated by Desulfovibrio oceani (Desulfovibrionales), Desulfobulbus sp, Desulfocapsa sp., Desulfosarcina, sp. (Desulfobacterales), Desulfatiglans sp. (Desulfarculales) as well as members of the SEEP-SRB1 and SRB4 groups (Desulfobacterales) belonging to the Deltaproteobacteria. SRB within the orders Desulfovibrionales and Desulfobacterales showed highest relative abundances up to $14 \%$ to the overall microbial community only at the carbonates from the Norfolk Canyon, Washington Canyon and Blake Ridge, all located in the Atlantic Margin. The remaining carbonates harbored SRBs with low relative abundances of $<4 \%$ or were completely absent (Fig. 2). Only two exceptions, Norfolk and Washington Canyons, had a considerably high relative abundance of ANME, up to $27 \%$, while SRB communities ranged between 10 and $14 \%$. In most instances, ANME made up to $16 \%$ relative abundance of the microbial communities in carbonates samples that hosted $<4 \%$ SRBs (Fig. 2).
The detection of methane-oxidizing archaea, especially relatives of the ANME2 might be lacking or be underrepresented due to the potential bias in EMP primer as recognized in a recent study [53]. ANME-2d cluster, which includes the members of the Candidatus Methanoperedenaceae which are capable of utilizing nitrate, nitrite, and manganese and do not need a bacterial partner [49, 52, 92] might be potentially lacking in the $16 \mathrm{~S}$ rRNA dataset due to a primer bias [53]. However, nitrate-dependent AOM has mostly been described in freshwater systems and not been widely discussed in deep-sea ecosystems.

\section{mcrA-based analyses revealed a diverse community of methane-oxidizing archaea}

In order to offset any potential primer biases caused by only analysis of the 16S rRNA gene [53], we separately amplified the functional gene for methane generation and oxidation, methyl-coenzyme reductase A, mcrA. A large diversity of $m c r A$-like sequences were seen across all samples (Fig. 3a). At this point, it is unknown what substrates in addition to methane these may act upon. As such, we focus on known euryarchaeotal clades that also includes novel clades within this group (Fig. 3b). Analysis of the $m c r A$ genes revealed the presence of nine distinct clades of sequences supported with high bootstrap values (>80\%) potentially affiliated to the former ANME-1 and ANME-2 clades, the Methanomicrobiales, the Methanosarcinales, Candidatus Methanoperedenaceae (Methanosarcinales), Candidatus Argoarchaeum (Methanosarcinales) and three novel clades (Fig. 3b).

Most sites contained diverse $m c r A$ gene types, with the lowest diversity seen in samples from Washington Canyon, while the highest diversity was seen in samples from Baltimore Canyon, Norfolk Canyon and Pea Island seeps. Sequences closely related to the Candidatus Methanoperedenaceae were detected at all carbonate sites via $m c r A$ gene analysis, but had not been observed in 16S rRNA gene analyses (Fig. 3b). Earlier investigations reported the dominance of ANME-1a-b and ANME-2a-c cluster oxidizing methane in syntrophy with SRB in carbonate habitats $[46,47,53]$ and several studies concerning marine environmental AOM systems are described supplying sulfate as electron acceptor [24]. Sulfate-dependent AOM has the lowest free energy yield needed for ATP generation among the possible electron acceptors thriving at the energetically limit for sustaining life, with estimates of Gibbs free energy yields between -16 and $-35 \mathrm{~kJ} \mathrm{~mol}^{-1}$ operating close to its thermodynamic equilibrium with an increase in enzymatic back flux of methane and sulfate [90, 93-95]. However, coupling AOM with nitrate and nitrite reduction yields significantly more energy even at lower dissolved methane concentrations and at a less apparent enzymatic back flux [90, 91]. Microbial nitrate reduction 


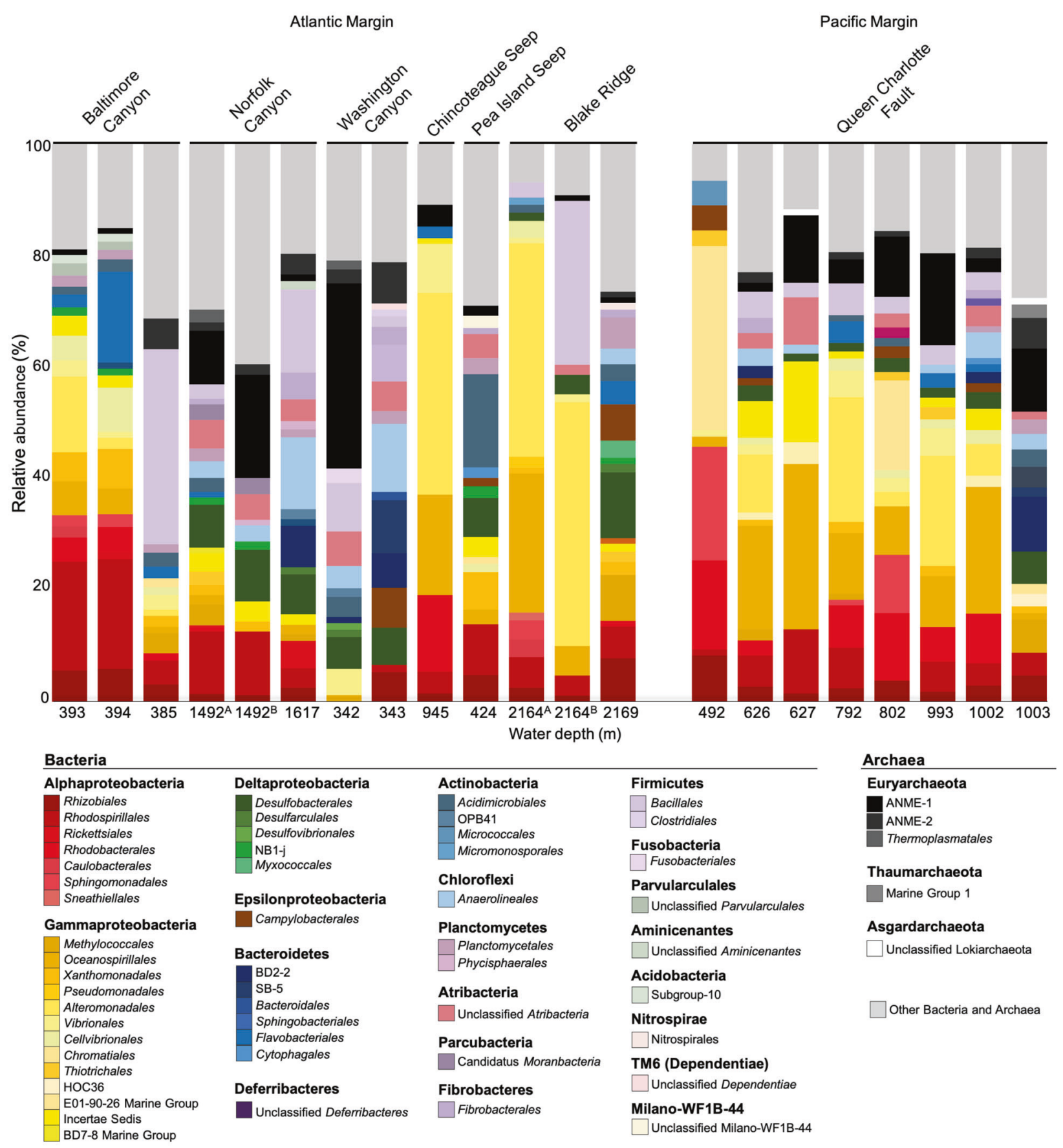

Fig. 2 Microbial community composition. Bacterial and archaeal community composition from carbonate samples of the Atlantic (A) and Pacific Margin (B) based on 16S rRNA gene sequencing. Colors

potentially utilizes nitrate from the bottom and sediment surface water where elevated nitrate concentrations were detected (Supplementary Fig. 1, Supplementary Table 1). Considering the wide diversity of Candidatus Methanoperedenaceae seen via $m c r A$ sequencing, and the apparent disconnect between methane-oxidizing archaea and SRB seen by 16S rRNA gene sequencing, this suggests the presence of partnership and electron flux scenarios of anaerobic methane- indicate members of different orders that account for at least $1 \%$ of the overall microbial abundance. Bar lengths represents relative abundance of the order in each sample.

oxidizing archaea beyond the canonical partnership with sulfate reducers.

\section{Metagenomic analysis of the microbial community}

To further investigate the metabolic pathways in carbonate samples, we reconstructed metagenome assembled genomes (MAGs) from metagenomic datasets generated for 
(A)

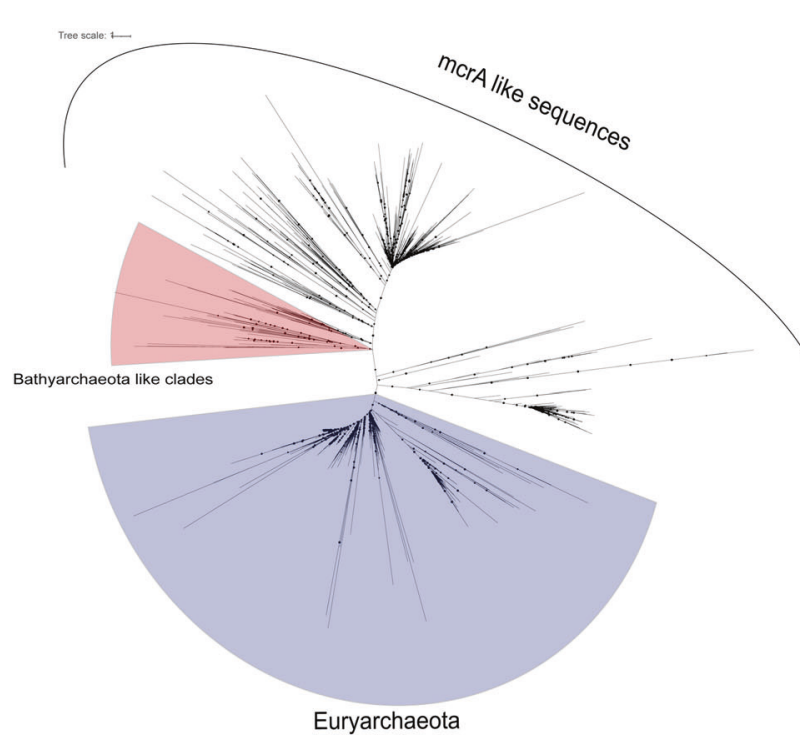

Fig. 3 mcrA phylogenetic trees. A Maximum likelihood phylogenetic trees of $m c r A$ gene sequences and mcrA-like-sequences deriving from amplicon and metagenomic sequencing from different carbonates sampled across the Atlantic and Pacific Margin. B Magnification of the

carbonates from the Atlantic (Norfolk Canyon) and Pacific (Queen Charlotte Fault) margins. These sites were chosen due to the diversity determined via $16 \mathrm{~S}$ rRNA analysis (Fig. 2). We successfully binned 23 MAGs from both seep sites, with completeness $>50 \%$ (median $=75.11)$ and low contamination levels $<7 \%$ (median $=3.475$ ) (Supplementary Table 2). Overall, MAG coverages were low (average $=16 \mathrm{x}$, lowest $=6 \mathrm{x}$ and highest $=47 \mathrm{x}$ ), which hindered the recovery of MAGs with higher completion levels. However, these MAGs have a sufficient quality to address the main purpose of this study.

A total of six MAGs showed phylogenetic affiliations to anaerobic methane oxidizers (ANME cluster 1 and 2) (Supplementary Fig. 2; Supplementary Table 2). Three out of the six MAGs contain the gene encoding for $m c r A$. The phylogenetic analysis of the detected $m c r A$ genes showed that they were closely related to ANME-1 and ANME-2 (Fig. 3). We explored the spectrum of final electron acceptors potentially used by the recovered MAGs with an emphasis on the ones belonging to ANME-1 and ANME-2. We employed a HMM search tool to screen a custom database representing the key genes involved in the aerobic and anaerobic respiration mechanisms including the ones targeting different oxidized nitrogen and sulfur species (Fig. 4). Overall, the majority of the recovered MAGs showed the potential to anaerobically respire different oxidized nitrogen (nitrate, nitrite, nitrous and nitric oxides) and sulfur (sulfate, sulfite, thiosulfate) species.

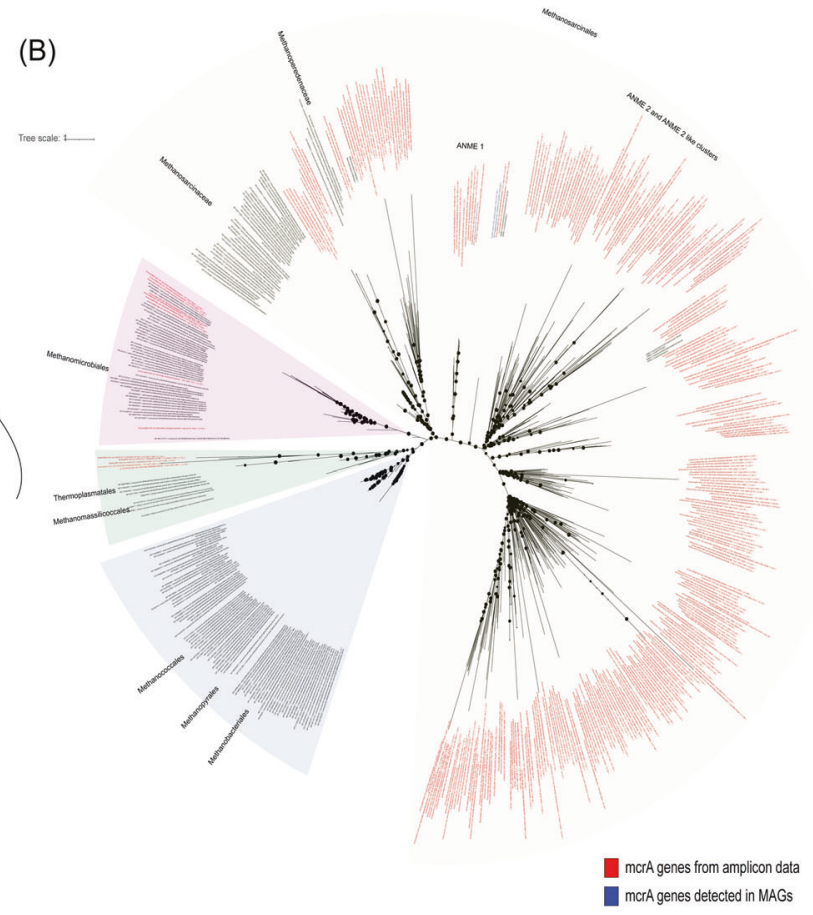

Euryarchaeota ANME clades (Tree A) including the mcrA sequences from the Queen Charlotte Fault (QCF, green dots) and Norfolk Canyon (NC, pink dots) MAGs.

The capacities to perform complete dissimilatory sulfate and sulfite reduction to sulfide (sat, aprAB, $d s r A B, a s r A B C$ ) were found in $\sim 70 \%$ of the recovered MAGs.

The phylogenetic analysis of the functional protein DsrA recovered from the MAGs grouped into two separate clades; one clade closely related to $d s r A$ sequences belonging to members affiliated to the Gammaprotebacteria and the other clade, composed of the $d s r A$ sequences recovered from the ANME archaeal bins, grouped in a separate clade closely related to Hydrothermoarchaeota sequences (Supplementary Fig. 3). The true affiliations of the DsrA proteins to the ANME bins were confirmed following this approach [96]: (1) the coverage values of the contigs encoding for the $d s r A$ proteins were calculated and plotted in relation to the $\mathrm{GC} \%$. This showed that $d s r A$ encoding contigs fall within the same coverage and $\mathrm{GC} \%$ ranges of the rest of the contigs in the same MAG (Supplementary Fig. 4); (2) We located DNA polymerase subunit B (DNA pol B) in the same scaffold encoding for $d s r A$ in Norfolk_bin_005. A phylogenetic tree of the DNA pol B was constructed and showed a close relation of the Norfolk_bin_005 DNA pol B sequence to DNA pol B sequences belonging to Methanophagale$s \_$ANME1 group. On the other hand, $d s r A$ encoding scaffold in QCF_bin022_004 was considerably short (1008 bps only) and encoding for two proteins (dissimilatory sulfite reductase and rubrerythrin family protein), none of them could be reliably used to evaluate the taxonomic position of 


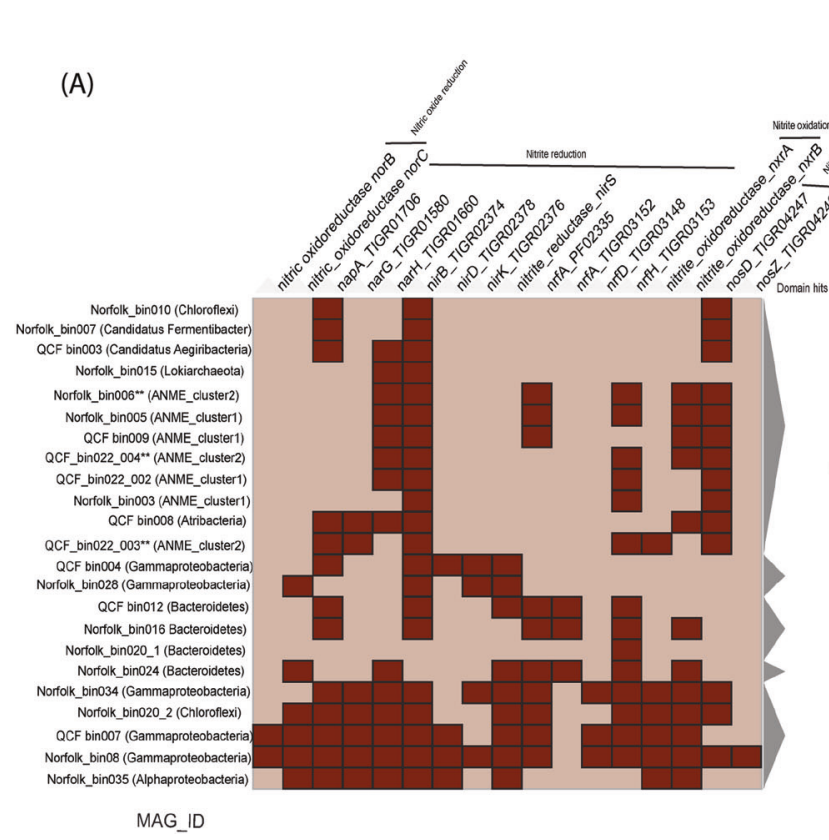

Fig. 4 Functional genes within MAGs. The potential capacity of the Carbonate MAGs to utilize different oxidized substrates as terminal electron acceptors (A) oxidized nitrogen species (B) oxidized sulfur species. In the heatmap, the recovered MAGs were clustered along the $X$-axis based on presence/absence profiles of the targeted genes, while

the scaffold. Therefore, we used the coverage and GC\% criteria only to confirm the affiliation of the scaffold to the QCF_bin022_004 MAG.

On the other hand, the full potential to perform complete reduction of oxidized nitrogen species including nitrate, nitrite and nitrous oxide (narGHI, napAB, nirBD, nirS, $n r f A H$, nosDZ) were encoded by limited number of MAGs affiliated to the Gammaproteobacteria, Alphaproteobacteria, and Chloroflexi lineages (Fig. 4). However, sporadic genes encoding for one or more proteins involved in the reduction of the different oxidized nitrogen species were observed in other lineages including MAGs belonging to ANME-1 and ANME-2 clusters. The incompleteness of the pathway within the ANME-1 and ANME-2 MAGs may be due to the lack of the function within these organisms or due to genome incompleteness. It is possible that ANME lineages inhabiting carbonate sites may be capable of mediating methane and other short-chain alkane oxidations independently using oxidized sulfur species as the terminal electron acceptor or in partnership with organisms capable of oxidized nitrogen species respiration (e.g., Gammaproteobacteria).

\section{Local in situ environment rather than seafloor depth dictates microbial community structure in carbonates}

The dissimilarity between microbial community structures detected in different carbonate samples is dictated by multiple

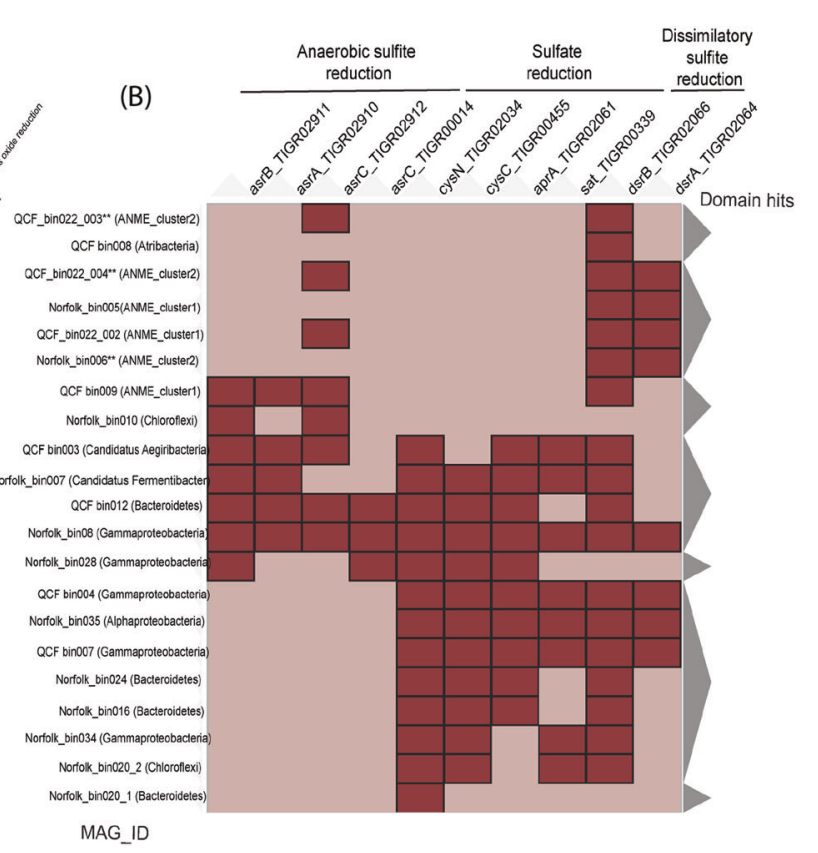

biogeochemical cycles and energy metabolism related genes are listed on the $Y$-axis. The clustering was performed using Jaccard distance and complete linkage methods. **denotes a MAG that is ANME and contains a gene for $m c r A$.

factors including prevalent geochemical and environmental conditions and the quality of the available carbon substrates and electron acceptors. We tested the dissimilarity between the microbial communities in different carbonate samples and identified potential conditions driving such differences. Our results based on 16S rRNA gene sequencing suggest significant differences between microbial community structures in the carbonate sites at the Atlantic and Pacific Margins (72.89\% dissimilarity, SIMPER analysis). The carbonate microbial community composition originating from Queen Charlotte Fault of the Pacific Margin was significantly distinct in comparison to the microbial communities from the carbonate samples collected from the USAM (ANOSIM, Baltimore Canyon $p=0.0068$, Norfolk Canyon $p=0.0062$, Washington Canyon $p=0.024$, Pea Island Seep $p=0.023$, Blake Ridge $p=0.0056$ ) with the exception of Chincoteague Seep (ANOSIM $p=0.066$ ). The most prominent difference in the community structure of the Queen Charlotte Fault carbonates was partially explained through the high abundances of bacterial members affiliated with Alpha- and Gammaproteobacteria with a relative abundance of up to $46 \%$ and $48 \%$, respectively (Fig. 2). Both classes explained $43.77 \%$ of the dissimilarity compared to the carbonates of the Atlantic Margin with mainly Uncultured Rhodospirillaceae (Rhodospirillales), Uncultured Rhodobacteraceae (Rhodobacterales), Uncultured Sphingomonadaceae (Sphingomonadales), Pseudoalteromonas tetraodonis (Alteromonadales), Halomonas venusta, Halomonas hydrothermalis, Alcanivorax 


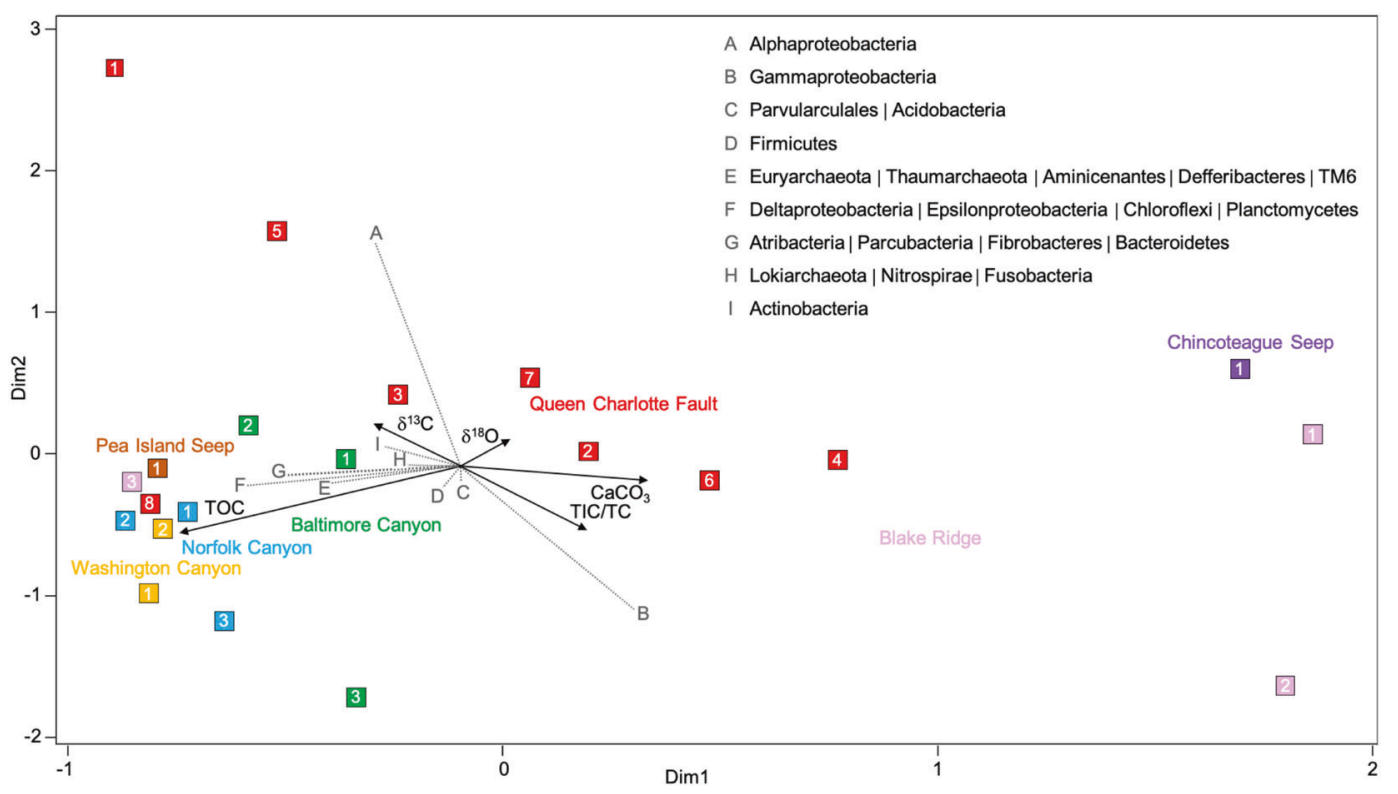

Fig. 5 Amplicon data and geochemical features. RDA plot of bacterial and archaeal 16S rRNA gene amplicons dataset comparing seven different carbonate seeps (highlighted in different colors) covering 21 sample locations (squares) distributed along the Atlantic and Pacific

venustensis, Cobetia sp. (Oceanospirillales), Thiogranum sp., Thiohalophilus sp. (Chromatiales) accounting for $40.90 \%$ of the dissimilarity (SIMPER analysis). The microbial communities from the carbonates collected from the Baltimore Canyon, Norfolk Canyon, Washington Canyon, Chincoteague Seep, Pea Island and Blake Ridge sites were not significantly different ( $T$-test, $p>0.3$ ).

ANMEs were detected in almost all carbonate sites at the Pacific and Atlantic Margin (Fig. 2), ANME-1b contributed up to $7.8 \%$ of the dissimilarity of the overall microbial community composition and $64.67 \%$ of the dissimilarity (SIMPER analysis) of the total ANME representatives from all sites. The depth of the sampling site did not impact the microbial community (ANOSIM $p>0.1$ ). However, the availability of carbon (e.g., total organic carbon, total inorganic carbon) potentially influences the microbial community structure (Fig. 5). The dissimilarity in microbial community structure between the carbonates from the Atlantic and Pacific Margin might be potentially due to differences in the available TOC, TIC, $\mathrm{CaCO}_{3}, \delta^{13} \mathrm{C}$ and $\delta^{18} \mathrm{O}$ (Fig. 5) suggesting a strong biogeographic partitioning present in the carbonate system based on these variables.

Despite methane, other potential carbon sources were previously reported in marine cold seeps including thermogenic hydrocarbons like short-chain alkanes and aromatic compounds providing alternative sources of carbon and electron for the microbial community. Various archaeal lineages are capable of utilizing short-chain alkanes, longer chain alkanes and aromatic hydrocarbons [97, 98]. Hence, the mcrA diversity seen in these samples is likely due to
Margin and illustrating the relationship to the different phyla (gray dotted lines with capital letters) and geochemical parameters $\left(\delta^{13} \mathrm{C}\right.$, $\delta^{18} \mathrm{O}$, TOC, TIC, TC, $\mathrm{CaCO}_{3}$; black arrows).

their wide metabolic functions targeting different hydrocarbons including methane as well as other short and long chain alkanes, and support novel partnerships (i.e., other than SRB) in environments that promote authigenic carbonate precipitation.

\section{Conclusion}

This is the first study to conduct a comparative investigation of microbial community composition of methane-derived authigenic carbonates from seep sites along the Atlantic and Pacific Margins. These surveys showed a broad biogeography across all sites, suggesting the presence of core microbiomes that dominate most of the authigenic carbonates and the variations within the communities mainly driven by the surrounding geochemical conditions. Also, we noted a large diversity via the mcrA gene-based survey. Functionally diverse methanotrophic archaea exist across the carbonates from the Atlantic and Pacific Margins, potentially capable of utilizing a broad range of electron acceptors. These potential alternative electron acceptors include oxidized nitrogen compounds, which could be abundant as part of a cryptic nitrogen cycle and fuel methane oxidation at cold seeps, and are suggested by the distribution of Candidatus Methanoperedenaceae across most sites. Metagenomic analysis revealed that ANME1 may not require partners and many other sulfate and nitrogen oxidizing bacteria exist as potential partners. These findings significantly extend our current views regarding the 
ANME physiology and the spectrum of electron acceptors and partners facilitating methane oxidation at cold seeps from different margin settings.

\section{Data availability}

Sequencing data are deposited at the NCBI Sequence Read Archive under accession numbers (PRJNA637917, PRJNA637905, PRJNA664522).

Acknowledgements We acknowledge all shipboard crews and scientists who assisted in the collection of these samples and support from the Bureau of Ocean Energy Management (BOEM) and the National Oceanic and Atmospheric Administration (NOAA) Office of Ocean Exploration and Research for ship support. Support from the University of Delaware Center for Bioinformatics and Computational Biology Core Facility and use of the BioHen cluster was made possible through funding from the Delaware INBRE (NIGMS P20GM103446), Delaware EPSCoR (NSF EPS-0814251, NSF IIA1330446), the State of Delaware, and the Delaware Biotechnology Institute. Funds were provided to NGP from the USGS Coastal and Marine Hazards and Resource Program and Environments Program.

\section{Compliance with ethical standards}

Conflict of interest The authors declare no competing interests.

Publisher's note Springer Nature remains neutral with regard to jurisdictional claims in published maps and institutional affiliations.

\section{References}

1. Bouloubassi I, Heijs SK, Pancost RD, Pierre C, Damsté JS, Gottschal JC, et al. $\mathrm{CH}_{4}$-consuming microorganisms and the formation of carbonate crusts at cold seeps. Earth Planet Sc Lett. 2002;203:195-203.

2. Lein AY, Ivanov MV, Pimenov NV, Gulin MB. Geochemical characteristics of the carbonate constructions formed during microbial oxidation of methane under anaerobic conditions. Microbiol. 2002;71:78-90.

3. Michaelis W, Seifert R, Nauhaus K, Treude T, Thiel V, Blumenberg M, et al. Microbial reefs in the Black Sea fuelled by anaerobic oxidation of methane. Science. 2002;297:1013-5.

4. Gulin SB, Polikarpov GG, Egorov VN. The age of microbial carbonate structures grown at methane seeps in the Black Sea with an implication of dating of the seeping methane. Mar Chem. 2003;84:67-72

5. Mahn JC, Day S, Martin JB, Greinert J, Rathburn T, McAdoo B. A study of the chemistry of pore fluids and authigenic carbonates in methane seep environments: Kodiak Trench, Hydrate Ridge, Monterey Bay, and Eel River Basin. Chem Geol. 2005;220:329-45.

6. Teichert B, Bohrmann G, Suess E. Chemoherms on Hydrate Ridge - unique microbially-mediated carbonate build-ups growing into the water column. Palaeo. 2005;227:67-85.

7. Naehr TH, Eichhubl P, Orphan VJ, Hovland M, Paull CK, Ussler III W. et al. Authigenic carbonate formation at hydrocarbon seeps in continental margin sediments: a comparative study. Deep Sea Res Part Ii. 2007;54:1268-91.

8. Reitner J, Peckmann J, Blumenberg M, Michaelis W, Reimer A, Thiel V. Concretionary methane-seep carbonates and associated microbial communities in Black Sea sediments. PALAEO 2005; 227:18-30.
9. Prouty NG, Sahy D, Ruppel CD, Roark EB, Condon D, Brooke S, et al. Insights into methane dynamics from analysis of authigenic carbonates and chemosynthetic mussels at newly-discovered Atlantic Margin seeps. Earth Planet Sc Lett. 2016;449:332-44.

10. Prouty NG, Campbell PL, Close HG, Biddle JF, Beckmann S. Molecular indicators of methane metabolisms at cold seeps along the United State Atlantic Margin. Chem Geol. 2020;543:119603.

11. Teichert B, Eisenhauer A, Bohrmann G, Haase-Schramm A, Bock B, Linke P. U/Th systematics and ages of authigenic carbonates from Hydrate Ridge, Cascadia Margin: recorders of fluid flow variations. Geochim Cosmochim Acta. 2003;67:3845-57.

12. Kutterolf S, Liebetrau V, Mörz T, Freundt A, Hammerich T, GarbeSchönberg D. Lifetime and cyclicity of fluid venting at forearc mound structures determined by tephrostratigraphy and radiometric dating of authigenic carbonates. Geology. 2008;36:707-10.

13. Skarke A, Ruppel C, Kodis M, Brothers D, Lobecker E. Widespread methane leakage from the sea floor on the northern US Atlantic margin. Nat Geosci. 2014;7:657-61.

14. Johnsen HP, Miller UK, Salmi MS, Solomon EA. Analysis of bubble plum distributions to evaluate methane hydrate decomposition on the continental slope. Geochem Geophys. 2015;16:3825-39.

15. Prouty NG, Brothers DS, Kluesner JW, Barrie JV, Andrews BD, Lauer RM, et al. Focused fluid flow and methane venting along the Queen Charlotte fault, offshore Alaska (USA) and British Columbia (Canada). Geosphere. 2020;16:1336-57.

16. Conrad R. The global methane cycle: recent advances in understanding the microbial processes involved. Environ Microbiol Rep. 2009;1:285-92.

17. Cui M, Ma A, Qi H, Zhuang X, Zhuang G. Anaerobic oxidation of methane: an "active" microbial process. MicrobiologyOpen 2015; $4: 1-11$.

18. Aloisi G, Pierre C, Rouchy JM, Foucher JP, Woodside J. Methane-related authigenic carbonates of eastern Mediterranean Sea mud volcanoes and their possible relation to gas hydrate destabilisation. Earth Planet Sc Lett. 2000;184:321-38.

19. Greinert J, Bohrmann G, Elvert M. Stromatolitic fabric of authigenic carbonate crusts: result of anaerobic methane oxidation at cold seeps in 4,850 m water depth. Int J Earth Sci. 2002;91:698-711.

20. Sun X, Turchyn AV. Significant contribution of authigenic carbonate to marine carbon burial. Nat Geosci. 2014;7:201.

21. Hoehler TM, Alperin MJ, Albert DB, Martens CS. Field and laboratory studies of methane oxidation in an anoxic marine sediment: evidence for a methanogen-sulfate reducer consortium. Glob Biogeochem Cy. 1994;8:451-63.

22. Hanson RS, Hanson TE. Methanotrophic bacteria. Microbiol Rev. 1996;60:439-71.

23. Orphan VJ, Hinrichs KU, Ussler W, Paull CK, Taylor LT, Sylva SP, et al. Comparative analysis of methane-oxidizing Archaea and sulfate-reducing bacteria in anoxic marine sediments. Appl Environ Microbiol. 2001;67:1922-34.

24. Valentine DL. Biogeochemistry and microbial ecology of methane oxidation in anoxic environments: a review. Antonie Van Leeuwenhoek. 2002;81:271-82.

25. Hinrichs K, Boetius A. The anaerobic oxidation of methane: new insights in microbial ecology and biogeochemistry. In Wefer G, Billett D, Hebbeln D, Jørgensen BB, Schlüter M, van Weering TCE, editors. Ocean Margin Systems. Berlin, Heidelberg: Springer; 2002.

26. Reeburgh WS. Oceanic methane biogeochemistry. Chem Rev. 2007; 107:486-513.

27. Valentine DL, Reeburgh WS. New perspectives on anaerobic methane oxidation. Environ Microbiol. 2008;2:477-84.

28. Knittel K, Boetius A. Anaerobic oxidation of methane: progress with an unknown process. Annu Rev Microbiol. 2009;63:311-34.

29. Pop R, Wenzhoefer F, Ramette A, Felden J, Boetius A. Spatial scales of bacterial community diversity at cold seeps (Eastern Mediterranean Sea). ISME J. 2015;9:1306-18. 
30. Knittel K, Boetius A, Lemke A, Eilers H, Lochte K, Pfannkuche $\mathrm{O}$, et al. Activity, distribution, and diversity of sulfate reducers and other bacteria in sediments above Gas Hydrate (Casadia Margin, Oregon). Geomicrobiol J. 2003;20:269-94.

31. Niemann H, Lösekann T, de Beer D, Elvert M, Nadalig T, Knittel $\mathrm{K}$, et al. Novel microbial communities of the Haakon Mosby mud volcano and their role as a methane sink. Nature. 2006;443:854-8.

32. Lösekann T, Knittel K, Nadalig T, Fuchs B, Niemann H, Boetius A, et al. Diversity and abundance of aerobic and anaerobic methane oxidizers at the Haakon Mosby Mud Volcano, Barents Sea. Appl Environ Microbiol. 2007;73:3348.

33. Haroon MF, Hu S, Shi Y, Imelfort M, Keller J, Hugenholtz P, et al. Anaerobic oxidation of methane coupled to nitrate reduction in a novel archaeal lineage. Nature 2013;500:567.

34. McGlynn SE, Chadwick GL, Kempes CP, Orphan VJ. Single cell activity reveals direct electron transfer in methanotrophic consortia. Nature. 2015;526:531-5.

35. Wegener G, Krukenberg V, Riedel D, Tegetmeyer HE, Boetius A. Intercellular wiring enables electron transfer between methantrophic archaea and bacteria. Nature 2015;526:587-90.

36. Greinert J, Bohrmann G, Suess E. Gas hydrate-associated carbonates and methane-venting at Hydrate Ridge: classification, distribution, and origin of authigenic lithologies. In Paull CK, Dillon WP, editors. Natural gas hydrates. Washington, DC: American Geophysical Union; 2001. p. 99-113.

37. Luff R, Wallmann K. Fluid flow, methane fluxes, carbonate precipitation and biogeochemical turnover in gas hydrate-bearing sediments at hydrate ridge, Cascadia margin: numerical modelling and mass balances. Geochim Cosmochim Acta. 2003;67:3403-21.

38. Luff R, Wallmann K, Aloisi G. Numerical modelling of carbonate crust formation at cold vent sites: significance for fluid and methane budgets and chemosynthetic biological communities. Earth Plan Sci Lett. 2004;221:337-53.

39. Lein A. Authigenic carbonate formation in the ocean. Lithol Min Resour. 2004;39:1-30.

40. Peckmann J, Thiel V. Carbon cycling at ancient methane-seeps. Chem Geol. 2004;205:443-67.

41. Blumenberg M, Seifert R, Reitner J, Pape T, Michaelis W. Membrane lipid patterns typify distinct anaerobic methanotrophic consortia. Proc Natl Acad Sci. 2004;101:11111-6.

42. Boetius A, Suess E. Hydrate Ridge: a natural laboratory for the study of microbial life fuelled by methane from near-surface gas hydrates. Chem Geol. 2004;205:291-310.

43. Heijs SK, Aloisi G, Bouloubassi I, Pancost RD, Pierre C, Damsté JSS, et al. Microbial community structure in three deep-sea carbonate crusts. Micro Eco. 2006;52:451-62.

44. Guan H, Sun Y, Zhu X, Mao S, Feng D, Wu N, et al. Factors controlling the types of microbial consortia in cold-seep environments: a molecular and isotopic investigation of authigenic carbonates from the South China Sea. Chem Geol. 2013;354:55-64.

45. Marlow JJ, Steele JA, Case DH, Connon SA, Levin LA, Orphan VJ. Microbial abundance and diversity patterns associated with sediments and carbonates from the methane seep environments of Hydrate Ridge. Or Front Mar Sci. 2014;1:1-16.

46. Marlow JJ, Steele JA, Ziebis W, Thurber AR, Levin LA, Orphan VJ. Carbonate-hosted methanotrophy represents an unrecognized methane sink in the deep sea. Nat J Commun. 2014;5:5094.

47. Marlow JJ, Peckmann J, Orphan VJ. Autoendoliths: a distinct type of rock-hosted microbial life. Geobiology. 2015;13:303-7.

48. Mason OU, Case DH, Naehr TH, Lee RW, Thomas RB, Bailey $\mathrm{JV}$, et al. Comparison of archaeal and bacterial diversity in methane see carbonate nodules and host sediments, Eel River Basin and Hydrate Ridge, USA. Environ Microbiol. 2015;70: 766-84

49. Raghoebarsing AA, Pol A, van de Pas-Schoonen KT, Smolders AJP, Ettwig KF, Rijpstra WIC, et al. A microbial consortium couples anaerobic methane oxidation to denitrification. Nature. 2006;440:918-21.

50. Green-Saxena A, Dekas AE, Dalleska NF, Orphan VJ. Nitratebased niche differentiation by distinct sulfate-reducing bacteria involved in the anaerobic oxidation of methane. ISME J. 2014;8: 150-63.

51. Kurth JM, Smit NT, Berger S, Schouten S, Jetten MSM, Welte CU. Anaerobic methanotrophic archaea of the ANME-2d clade feature lipid composition that differs from other ANME archaea. FEMS Microbiol Ecol. 2019;95:fiz082.

52. Leu AO, Cai C, McIlroy SJ, Southam G, Orphan VJ, Yuan Z, et al. Anaerobic methane oxidation coupled to manganese reduction by members of the Methanoperedenaceae. ISME J. 2020;14: 1030-41.

53. Case DH, Pasulka AL, Marlow JJ, Grupe BM, Levin LA, Orphan VJ. Methane seep carbonates host distinct, diverse, and dynamic microbial assemblages. mBio 2015;6:e01348-15.

54. Ruff SE, Biddle JF, Teske AP, Knittel K, Boetius A, Ramette A. Global dispersion and local diversification of the methane seep microbiome. Proc Natl Acad Sci USA. 2015;112:4015-20.

55. Brothers LL, VanDover CL, German CR, Kaiser CL, Rupple CD, Lobecker E, et al. Evidence for extensive methane venting on the southeastern U.S. Atlantic margin. Geol. 2013;41:807-10.

56. Ruppel CD, Kessler JD. The interaction of climate change and methane hydrates. Reviews of Geophysics. 2017;55:126-68.

57. Seeberg-Elverfeldt J, Schlüter M, Feseker T, Kölling M. Rhizon sampling of porewaters near the sediment-water interface of aquatic systems. Limnol Oceanogr Methods. 2005;3:361-71.

58. Caprasso JG, Lauber CL, Walters WA, Bery-Lyons D, Lozupone CA, Turnbaugh PJ, et al. Global patterns of 16S rRNA diversity at a depth of millions of sequences per sample. PNAS. 2011;108: 4516-22.

59. Apprill A, McNally S, Parsons R, Weber L. Minor revision to V4 region SSU rRNA 806R gene primer greatly increases detection of SAR11 bacterioplankton. AME 2015;75:129-37.

60. Parada AE, Needham DM, Fuhrman JA. Every base matters: assessing small subunit rRNA primers for marine microbiomes with mock communities, time series and global field samples. Environ Microbiol. 2016;18:1403-14.

61. Luton PE, Wayne JM, Sharp RJ, Riley PW. The $m c r A$ gene as an alternative to $16 \mathrm{~S}$ rRNA in the phylogenetic analyses of methanogen populations in landfill. Microbiol. 2002;148:3521-30.

62. Lange V, Bohme I, Hofmann J, Lang K, Sauter J, Schone B, et al. Cost-efficient high-throughput HLA typing by MiSeq amplicon sequencing. BMC Genom. 2014;15:63.

63. Edgar RC. Search and clustering orders of magnitude faster than BLAST. Bioinformatics 2010;26:2460-1.

64. Quast C, Pruesse E, Yilmaz P, Gerken J, Schweer T, Yarza P, et al. The SILVA ribosomal rRNA gene database project: improved data processing and web-based tools. Nucleic Acids Res. 2013;41:590-6.

65. Clarke KR. Non-parametric multivariate analyses of changes in community structure. Aus J Ecol. 1993;18:117-43.

66. Bolger AM, Lohse M, Usadel B. Trimmomatic: a flexible trimmer for Illumina sequence data. Bioinformatics 2014;30:2114-20.

67. Li D, Liu CM, Luo R, Sadakane K, Lam TW. MEGAHIT: an ultra-fast single-node solution for large and complex metagenomics assembly via succinct de Bruijn graph. Bioimformatics 2015;31:1674-6.

68. Wu YW, Simmons BA, Singer SW. MaxBin 2.0: an automated binning algorithm to recover genomes from multiple metagenomic datasets. Bioinformatics 2015;32:605-7.

69. Parks DH, Imelfort M, Skennerton CT, Hugenholtz P, Tyson GW. CheckM: assessing the quality of microbial genomes recovered from isolates, single cells, and metagenomes. Genome Res. 2015; 25:1043-55. 
70. Laczny CC, Sternal T, Plugaru V, Gawron P, Atashpendar A, Margossian $\mathrm{HH}$ et al. VizBin - an application for referenceindependent visualization and human-augmented binning of metagenomic data. Microbiome. 2015;3:1.

71. Seah BK, Gruber-Vodicka HR. gbtools: interactive visualization of metagenome bins. Front Microbiol. 2015;18:1451.

72. Bushnell B. Bbmap: a fast, accurate, splice-aware aligner No. LBNL-7065E. Berkeley, CA: Ernest Orlando Lawrence Berkeley National Laboratory; 2014.

73. Kumar S, Jones M, Koutsovoulos G, Clarke M, Blaxter M. Blobology: exploring raw genome data for contaminants, symbionts, and parasites using taxon-annotated GC-coverage plots. Front Genet. 2013;4:237.

74. Bankevich A, et al. SPAdes: a new genome assembly algorithm and its applications to single-cell sequencing. J Comput Biol. 2012;19:455-77.

75. Olm MR, Brown CT, Brooks B, Banfield JF. dRep: a tool for fast and accurate genomic comparisons that enables improved genome recovery from metagenomes through de-replication. ISME J. 2017;11:2864-8.

76. Hyatt D, Chen GL, LoCascio PF, Land ML, Larimer FW, Hauser LJ. Prodigal: Prokaryotic gene recognition and translation initiation site identification. BMC Bioinforma. 2010;11:119.

77. Seeman T. Prokka: rapid prokaryotic genome annotation. Bioinformatics 2014;30:2068-9.

78. Kanehisa M, Sato Y, Morishima K. BlastKOALA and GhostKOALA:KEGG tools for functional characterization of genome and metagenome sequences. JMB. 2015;428:726-31.

79. Brown CT, Olm MR, Thomas BC, Banfield JF. Measurement of replication rates in microbial communities. Nat Biotechnol. 34:1256-63.

80. Diamond S, et al. Mediterranean grassland soil C-N compound turnover is dependent on rainfall and depth, and is mediated by genomically divergent microorganisms. Nat Microbiol. 2019;4: 1356-67.

81. Nguyen L-T, Schmidt HA, von Haeseler A, Minh BQ. IQ-TREE: a fast and effective stochastic algorithm for estimating maximumlikelihood phylogenies. Mol Biol Evol. 2015;32:268-74.

82. Miller MA, Pfeiffer W, Schwartz T. Creating the CIPRES science gateway for inference of large phylogenetic trees. In: 2010 Gateway Computing Environments Workshop (GCE). New Orleans, LA: Institute of Electrical and Electronics Engineers; 2010. p.1-8.

83. Anantharaman K, Brown CT, Hug LA, Sharon I, Castelle CJ, Probst AJ, et al. Thousands of microbial genomes shed light on interconnected biogeochemical processes in an aquifer system. Nat Commun. 2016;7:13219.

84. Edgar RC. MUSCLE: multiple sequence alignment with high accuracy and high throughput. Nucleic Acids Res. 2004;32: 1792-7.
85. Mendler K, Chen H, Parks DH, Lobb B, Hug LA, Doxey AC. AnnoTree: visualization and exploration of a functionally annotated microbial tree of life. Nucleic Acids Res. 2019;47:4442-8.

86. Whiticar MJ. Carbon and hydrogen isotopic systematics of bacterial formation and oxidation of methane. Chem Geol. 1999;161: 291-314.

87. Niewohner C, Hensen C, Kasten S, Zabel M, Schulz HD. Deep sulfate reduction completely mediated by anaerobic methane oxidation in sediments of the upwelling area off Namibia. Geochim Cosmochim Acta. 1998;62:455-64.

88. Borowski WS, Paull CK, Ussler W. Global and local variations of interstitial sulfate gradients in deep-water, continental margin sediments: Sensitivity to underlying methane and gas hydrates. Mar Geol. 1999;159:131-54.

89. Valentine DL, Kastner M, Wardlaw GD, Wang XC, Purdy A, Bartlett H. Biogeochemical investigations of marine methane seeps, Hydrate Ridge, Oregon. J Geophys Res. 2005;110:17.

90. Holler T, Wegener G, Niemann H, Deusner C, Ferdelmann TG, Boetius A, et al. Carbon and sulfur back flux during anaerobic microbial oxidation of methane and coupled sulfur reduction. PNAS 2011;108:E1484-E1490.

91. Timmers PHA, Welte CU, Koehorst JJ, Plugge CM, Jetten MSM, Stams AJM. Reverse methanogenesis and respiration in methanotrophic archaea. Archaea. 2017:1654237.

92. Arshad A, Speth DR, de Graaf RM, Op den Camp HJ, Jetten MS, Welte U. A metagenomic-based metabolic model of nitratedependent anaerobic oxidation of methane by Methanoperedenslike archaea. Front Microbiol. 2015;6:1423.

93. Valentine DL, Reeburgh WS. New perspectives on anaerobic methane oxidation. Environ Microbiol. 2000;2:477-84.

94. Sorensen KB, Finster K, Ramsing NB. Thermodynamic and kinetic requirements in anaerobic methane oxidising consortia exclude hydrogen, acetate and methanol as possible electron shuttles. Micro Ecol. 2001;42:1-10.

95. Yoshinaga MY, Holler T, Goldhammer T, Wegener G, Pohlman JW, Brunner B, et al. Carbon isotope equilibration during sulphatelimited anaerobic oxidation of methane. Nat Geosci. 2014;7:190-4.

96. Farag IF, Biddle JF, Zhao R, Martino AJ, House CH, Leon, et al. Metabolic potentials of archaeal lineages resolved from metagenomes of deep Costa Rica sediments. ISME J. 2019;14:1345-58.

97. Orcutt BN, Joye SB, Kleindienst S, Knittel K, Ramette A, Reitz $A$, et al. Impact of oil and higher hydrocarbons on microbial diversity, distribution, and activity in Gulf of Mexico cold-seep sediments. Deep Sea Res Pt Ii. 2010;57:2008-21.

98. Suess E. Marine cold seeps and their manifestations: geological control, biogeochemical criteria and environmental conditions. Int J Earth Sci. 2014;103:1889-916.

99. Ryan WBF, Carbotte JC, O'Hara S, Melkonian A, Arko R, Weissel RA, et al. Global Multi-Resolution Topography (GMRT) synthesis data set. Geochem Geophys Geosyst. 2009;10:Q03014. 